\title{
JAZF1 wt Allele
}

National Cancer Institute

\section{Source}

National Cancer Institute. JAZF1 wt Allele. NCI Thesaurus. Code C73543.

Human JAZF1 wild-type allele is located within 7p15.2-p15.1 and is approximately $350 \mathrm{~kb}$ in length. This allele, which encodes juxtaposed with another zinc finger protein 1, may play a role in the modulation of transcription. A chromosomal aberration involving this gene, translocation $\mathrm{t}(7 ; 17)(\mathrm{p} 15 ; \mathrm{q} 21)$ with the SUZ12 gene, is associated with endometrial stromal tumors. 